\title{
The Role of Business in the World Economy*
}

Sir Reay Geddes

The world business cornmunity, as represented in the International Charnber of Cornmerce, has studied the Brandt Report with great interest and care. It accepts the irnportance and urgency of the issues treated and subscribes wholeheartedly to the central airns which have inspired its authors. Like thern, the business cornmunity abhors poverty, disease, malnutrition and illiteracy, considering their elimination to be both a moral irnperative and the main route to social progress. It would also be good for business.

The Brandt Report changes a rather passive acceptance of inter-dependence into the more active challenge, for all states, of building on their mutual interest and working for greater prosperity in all parts of the world. Herr Brandt's introduction also appeals specifically to 'technicians and managers, to nembers of the rural and business cornmunities'-in short the private sector. So far, so good. So we looked for the description of the political and economic environment through the 1980s, in which to find opportunities to contribute more.

In this respect the Report surprised us. It does not seern to have noticed how fast the real world econorny has been and is evolving. In the 1970s a growing number of developing countries have come to ignore the rhetoric of the $1950 \mathrm{~s}$ and $1960 \mathrm{~s}$, propagated in their narne under the intellectual leadership of Raul Prebisch. They have rurnbled the exclusive, centrally planned nonsense of yesteryear. They are looking to competitive enterprise as the powerhouse in their developrnent.

Who would guess from the Brandt Report or from UN debates, as most relationships on a working level are bilateral, that there are now almost 200 bilateral treaties for the protection (and so the encouragernent) of international private investrnent to which developing countries are parties? Or that the UN itself is showing signs of responding to the new reality? The so-called Mexico Resolution, unanirnously adopted earlier this year at the Sixth Session of the UN Cornmission on Transnational Corporations and subsequently confirrned by ECOSOC, acknowledged - albeit fleetingly - the contribution of rnultinationals to the developrnent effort.

\footnotetext{
* A longer version of this paper was presented at a one-day conference on "The Brandt Report: Implications for International Business and Finance'. held in London on December 4. 1980.
}

In the second place, the Report has over-ernphasised the strict division of the world into so-called North and South, rich and poor, haves and have-nots. Such a division rnay offer a convenient political shorthand but it looks rnore artificial and inaccurate as each year passes. As such it has introduced unnecessary and sterile conflict into developrnent discussions and diverted attention from the real issues of desirable growth. The world econorny cornprises a changing spectrum of countries at every stage of econornic developrnent, and to ignore this is to dirninish the prospects of a better understanding of the developrnent process.

In this context, it seerns to us odd that the Report rnakes little more than passing reference to the socalled NICs, the newly-industrialised countries whose growing numbers are already a major force in the world econorny. It is neither a contribution to the intellectual debate nor helpful to the more backward developing countries to lump then all into one virtually hornogeneous category. The dynarnics of development need to be more fully understood, and the lessons of success more widely applied. It was unfortunate, to say the least, that, with the debatable exception of Malaysia, no nember of the Brandt Cornmission was a citizen of a NIC. The successful developing countries are, no doubt, more interested in making progress than staternents. It should be an object of diplomacy to bring thern rnore fully into the debate.

Thirdly, the Report focusses excessive attention on redistribution of wealth, to the comparative neglect of wealth creation. It is unfortunately true that much of the developrnent debate is preoccupied with the reaction of rich country governments to Third World dernands for increased official transfers. It was thus understandably a principal issue for the Brandt Cornmission. However, as a consequence, the inportance of wealth creation and the conditions which promote it rnost rapidly have been relatively ignored. The ICC membership regrets that the Brandt Report reinforces this imbalance since we believe that the 'transfer of resources' is not in itself the means by which adequate and sustainable developrnent will be pronoted.

Further, preoccupation with transfers of official aid has the darnaging consequence of encouraging the inpression in the developing countries that government is the source of wealth and prosperity. It is one of many factors which, throughout the developing world,

Bulletin. 1981. vol 12 no 2. Institute of Development Studies. Sussex 
have led to a disdain for market mechanisms and a preference for bureaucratic planning of econornies. The Brandt Report lends its authority to the belief that central regulation is virtuous and can 'solve' problerns. This apparent faith in the capacity of official cornrnittees to make a host of complex choices seerns to us a triurnph of hope over experience. Moreover, the Report further strengthens this essentially political approach by appearing to accept that what chiefly determines the rnaterial welfare of countries is not the extent and efficiency of their productive capacity but their bargaining power in relation to other countries. It is an Alice-in-Wonderland world where prosperity flows not from factory or farm but from government offices and UN Resolutions.

Centralised econornic control has impeded the developrnent efforts of many poor countries. After two or three decades' experience, we no longer need to theorise; we can observe the record. And the record is that open, decentralised econornies which encourage the individual entrepreneur and respect narket forces outpace the rest. It is, of course, sornetirnes clairned that developing countries require large state sectors and centralised econornies because they lack indigenous entrepeneurs. But if the state is successfully to pronote econornic activity, the public sector requires the same scarce entrepreneurial talents. If a country is short of entrepeneurs, extension of the econornic dornain of governments is unlikely to remedy the deficiency. To burden their civil servants with additional entrepreneurial responsibilities before they are able to carry out effectively the basic administrative duties of government is asking for trouble.

Of course, official aid has an important role to play in the developrnent effort-especially in relation to the most backward countries where a prirnary function is the essentially charitable one of relieving absolute poverty and averting farnines and epidernics. It can also rnake a vital contribution by helping to develop a country's human resources and basic infrastructure, for business cannot operate efficiently with illiterate and unhealthy people with prirnitive cornrnunications systerns. Aid can obviously be a rnajor factor in creating the substructure for production and exports. But my point is that an excessive aid-oriented approach to developrnent can be harrnful-and the Brandt Report aligns itself with such an approach. I have already mentioned its tendency to lend weight to the conviction that government is the source of wealth. But, in addition, it concentrates attention on the arnount of resources available to the developing countries to the relative neglect of the efficiency' with which those resources are used. As the Pearson Cornmission pointed out more than ten years ago, 'the correlation between the amounts of aid received in the past decades and growth performance is very weak'. It is now increasingly appreciated that the progress of rnany developing countries is retarded, not so much by a shortage of finance as by a shortage of the desire and of the technical and organisational skills at different levels to absorb capital in productive investrnent. And, frequently, such countries have been unable to take effective advantage of available finance because of inappropriate internal econornic policies which only they can change.

Finally, the aid-oriented approach has ternpted the industrialised countries to take the easier course for them of offering aid instead of trade-that is to say, instead of opening up their dornestic markets to Third World exports and paying for thern with exports of capital goods. The liberalisation of the world econorny remains a principal preoccupation of the ICC and we have lent strong support to successive postwar initiatives to liberate trade in manufactures, connodities and now services. The broad-based Consurner Council supports this also.

The long-standing preoccupation with aid-giving has thus frequently distracted attention from adequate recognition of the role of international trade in wealth creation and development.

Finally, the Report, it seerns, neglects the most irnportant ingredients in developrnent. For, when all the rhetoric is spent, who actually creates the wealth on the ground? Who turns World Bank loans into darns and roads and schools and hospitals? Who possesses the know-how to put official aid to productive use? Who creates and owns the technology to be transferred? Who pays taxes? Private people and companies. And, after all, the countries which possess the resources which Brandt wishes to transfer have grown essentially in the private sector. Within the developing world itself, it is those countries which have facilitated and encouraged this endeavour which have made most progress towards industrialisation and the basis for a prosperous and self-reliant econorny.

It is then the prospect of harnessing and adapting more widely and effectively the reservoir of technical and organisational expertise possessed by the business cornmunities that holds out real hope for more rapid econornic development world-wide. Governments can alleviate poverty through aid transfers. But it is to the business community we must look if poverty is to be eventually eliminated. The principal development issue is how to enable the developing countries to increase their own capacity for wealth creation. To underrate this, as Brandt does, constitutes a disservice to countries at earlier stages of development. 
The international business conmunity already makes a major contribution to development. Private financial flows to the developing world already arnount to virtually double official flows. Taken together, they are only a supplement to the productive effort within the countries. In addition, there are the transfers of managerial and specialist skills and technology on a scale that belittles the activities of governments.

The business community - both national and international-could and would do more given the necessary encouragement by governments. The Brandt Report acknowledges in places the contribution of business to development-including the contribution of the multinational enterprises. But it does so by way of passing reference rather than offering proposals to enhance it. The emphasis is essentially on centralised control of economic life and regulation of business activity. As a result the Report rnay have the unfortunate effect of reinforcing the suspicion of private business which still prevails within some Third World governments and which is seriously inhibiting their countries' economic developrnent.

The Brandt Report places its ernphasis on the need for action at the global level-though it does concede that "changes in the international systern alone will not suffice'. This ernphasis is strange. Surely it is primarily to internal factors within each developing country that we rnust look for the key to rnore rapid progress. However well-endowed a country may be in natural resources, it will not attract the productive investrnent and know-how to exploit thern unless it provides an adrninistrative and legal frarnework which encourages enterprise and risk-taking. Business needs to know whether a country's government is stable and creditworthy internationally; whether its development priorities are economically sound and consistent; whether a high standard of law and order is rnaintained; whether there is social harmony; whether the public administration is efficient, expeditious and honest; whether there is full legal enforcement of contracts and protection of property rights, including tradernarks and patents; whether taxation levels on business and individuals are reasonable; whether foreign investors are subject to equitable conditions concerning profit repatriation and requirements with respect to local equity participation; whether there are fiscal incentives for investment; whether there is a high level of inflation; whether the government imposes controls on prices, profits, dividends, wages, or expansion of capacity; whether the work force possesses an adequate level of general education, and is rnobile, industrious and easily trained; whether the country's comrnunications infrastructure is adequate; whether the government welcornes and encourages both private entrepreneurial activity and constructive comrnunication with the business sector at the formative stages of policy making.

These are the more important factors which determine the extent to which private business is willing and able to contribute to the development effort, and they count for far more in the wealth creation process than any arnount of 'Unctalk' or resolutions. Very many of thern are within the control of governments. In those developing countries whose governments have succeeded in meeting a goodly proportion of these needs, the business cornmunity has responded with considerable dynarnism, flexibility and irnagination. It is our hope that the success of such countries will continue to provoke imitation across a much wider spread of the developing world. 